\title{
The degree of urbanisation in Brazil ${ }^{*}$
}

Maria do Carmo Dias

Bueno

Brazilian Institute of Geography and Statistics

Center for Information

Documentation and

Dissemination, Brazil

E-mail: maria.bueno@ibge.gov.br

Ricardo Neves de Souza Lima

Brazilian Institute of Geography and Statistics

Center for Information

Documentation and

Dissemination,

Brazil

E-mail: ricardo.lima@ibge.gov.br Keywords:
degree of urbanisation, IBGE methodology intends to provide local and

Brazil, detailed results, the purpose of the other two population grid methodologies is global and more generic.

Urban and rural are two central concepts used by a wide range of policymakers, researchers, national administrations, and international organisations. An option for defining urban areas is the use of the degree of urbanisation, a measure that classifies an area within a region based on a range of factors including population size, population density, the degree and extent of the built-up area, and many other concepts.

A new approach proposed jointly by the Directorate-General for Regional and Urban Policy, European Commission (DG REGIO) the Organisation for Economic Cooperation and Development (OECD) not only uses the traditional criterion of population density to determine the degree of urbanisation, but it also includes a contiguity rule, and it is applied to spatial units of the same size ( $1 \mathrm{~km}^{2}$ grid square cells).

The authors have performed a comparison study using this new approach and two other methodologies, one proposed by the OECD in 2011 and the other developed by the Brazilian Institute of Geography and Statistics (IBGE) in 2017. The results demonstrate that the degree of urbanisation for $42 \%$ of the Brazilian municipalities was the same using any of the three methods. The results using the DGREGIO/OECD approach and the IBGE methodology matched for approximately $70 \%$ of the municipalities.

Concerning the differences observed in the results of the test, it is necessary to consider the

* Disclaimer: This paper should not be reported as representing the views of the Brazilian Institute of Geography and Statistics; the views expressed here are those of the authors.

Regional Statistics, Vol. 9. No. 1. 2019: 72-84; DOI: 10.15196/RS090101 


\section{Introduction}

The traditional distinction between urban and rural areas within a country has assumed that urban areas, no matter how they are defined, provide a different way of life and usually a higher standard of living than rural areas. However, the criteria for defining areas that are urban vary widely from one country to another.

The simplest criterion used is population density, calculated by total population divided by the total land area. For small geographic areas, this measure relates closely to observable patterns of development and settlement. At higher levels of geography (municipalities, regions, and others), population density becomes a gross measure. Consequently, areas of low density can be masked by areas of very high density.

An alternative measure of defining urban areas is the degree of urbanisation. Areas within a region are classified as urban based on a range of factors including population size, population density, the degree and extent of built-up area, and many other concepts.

Another option for defining urban areas is using measurements of the extent or concentration of urban land use and land cover, such as impervious surfaces, builtup areas, or transportation network density. Unfortunately, these land use/land cover-based definitions are rarely linked to population-based definitions and limit the ability to bridge urban areas defined using these different approaches (Rain et al. 2007).

Usually, urban areas are defined by individual national governments according to internal administrative rules. This lack of a standard makes international data incomparable or at least increases the degree of uncertainty in measures derived from this information. Concerning the geographic unit used in rural-urban classification, the UN recommend, both for national purposes and for international comparability, the use of the locality. If this is not possible, the recommendation is the smallest administrative division of the country (UN 2014). However, these units can vary in character as well as in size between countries, within countries, and over time. This dependence on administratively defined geographies for classification of rural and urban sites makes comparisons very difficult.

Despite the differences in the definition of urban areas, some agencies that act globally need to make comparisons and evaluations between countries to define their policies in social and economic fields. In such cases, the establishment of an internal definition is an option. Therefore, to account for differences between rural and urban areas, the OECD established a regional typology, classifying local administrative areas as predominantly urban, intermediate, or predominantly rural, according to the share of the rural and urban population (OECD 2011). This typology is based essentially on the percentage of the population living in urban or rural localities and has proved to be meaningful in explaining the regional differences in economic and labour market

Regional Statistics, Vol. 9. No. 1. 2019: 72-84; DOI: 10.15196/RS090101 
performance. The problem with this methodology is that it relies on the population size of local administrative areas as the main criterion. If a local administrative area is large, even the presence of a dense city will lead to it being classified as thinly populated or a predominantly rural area.

A new approach proposed jointly by the DG REGIO and the OECD uses the criteria of population density and contiguity applied to units of analysis of the same size $\left(1 \mathrm{~km}^{2}\right.$ square cells). As the grid cells are identical, this method eliminates the distortion of using areas that vary in size and produce results that are less distorted and more comparable (Dijkstra-Poelman 2014). Besides that, the grid-based perspective offers a useful basis for regional statistical analysis since many economic, social, and environmental phenomena do not strictly follow administrative boundaries and needs more flexible geographies (Brandmueller et al. 2017). This new methodology needs to be tested and validated to demonstrate that its global adoption is both valuable and suitable. The details and results of this assessment are detailed in the next section.

\section{Study case}

\section{Goal}

The goal of this study is to test the methodology for classifying the level of urbanisation proposed by the DG REGIO/OECD using the best available data in Brazil. The study compares the results of this new methodology to two others: the regional typology proposed by the OECD in 2011 and the recent national classification for municipalities released by the IBGE in 2017.

\section{Data and methods}

OECD Regional Typology

The OECD Regional Typology is based on population density and the size of the urban centres located within a region. The methodology is composed of three steps (OECD 2011):

1. the classification of local administrative units as rural if their population density is below 150 inhabitants $/ \mathrm{km}^{2}$;

2. the classification of local administrative units as predominantly urban, intermediate, and predominantly rural if the percentage of the rural population is lower than $15 \%$, is equal or higher than $15 \%$ and lower than $50 \%$, or is higher than $50 \%$, respectively;

3. adjusting the classification based on the following rules: 
- A unit classified as predominantly rural becomes intermediate if it contains an urban centre with more than 200,000 inhabitants, representing at least 25\% of the regional population.

- A unit classified as intermediate becomes predominantly urban if it contains an urban centre with more than 500,000 inhabitants, representing at least 25\% of the regional population.

Data used in this methodology is the number of people in the enumeration areas of the 2010 Population Census, classified as rural or urban. Following the recommendations of the UN for the population census, the IBGE adopts a simple classification of the enumeration areas for statistical purposes - rural and urban. Most of the inputs to establish this classification come from the current local legislation. For municipalities lacking any local law concerning rural-urban boundaries, the classification is based on observed local patterns of settlement. The sum of the population for each class of enumeration area inside a municipality gives the total urban and rural population for this administrative level.

DG REGIO/OECD methodology

The approach recommended by the European Commission and developed by DG REGIO with the cooperation of the OECD brings a new degree of urbanisation that uses not only population density as a criterion but also a spatial criterion of contiguity applied to square grid cells sized $1 \mathrm{~km}^{2}$. The first step of the methodology is the definition of three regions (Dijkstra-Poelman 2014):

- high-density cluster: contiguous grid cells with a density of at least 1,500 inhabitants $/ \mathrm{km}^{2}$ and a minimum population of 50,000 inhabitants;

- urban cluster: contiguous grid cells with a density of at least 300 inhabitants $/ \mathrm{km}^{2}$ and a minimum population of 5,000 inhabitants;

- rural grid cells: grid cells outside urban and high-density clusters.

After the definition of these three regions, we can achieve the degree of urbanisation for an administrative area using the rules below (Dijkstra-Poelman 2014):

- densely populated area: an area in which at least $50 \%$ of the population is living in high-density clusters.

- intermediate density area: an area in which less than $50 \%$ of the population is living in rural grid cells, or less than $50 \%$ of the population lives in a highdensity cluster.

- thinly populated area or rural area: an area in which at least $50 \%$ of the population is living in rural grid cells.

Population data used to apply this method comes from the Brazilian population grid released in 2015, with information from the 2010 Population Census. The population grid was generated using a hybrid method, a mix of bottom-up and top-down approaches. The bottom-up or aggregation approach uses population

Regional Statistics, Vol. 9. No. 1. 2019: 72-84; DOI: 10.15196/RS090101 
census microdata and their location attributes. The approach was put into practice through the combination of two types of data: geographic coordinates of households in rural areas and street block segments properly geocoded in urban areas. The disaggregation or top-down approach was used in cases where the aggregation was not possible due to the absence of location data. The disaggregation approach uses spatial and statistical methods, with or without ancillary data, for the spatial transfer of data from enumeration areas to grid cells. The ancillary data used were layers of land use-land cover classification in rural areas and layers of the road system in urban areas. The Brazilian Population Grid can be considered excellent for $80 \%$ of the country, where the bottom-up approach was used, and quite good for the other 20\%, where the top-down approach was used (IBGE 2016).

Urban and rural sites of Brazil - IBGE classification for Brazilian municipalities

Recently, in July 2017, the IBGE published a national classification for municipalities concerning their degree of urbanisation (IBGE 2017) that aligned with the OECD Extended Regional Methodology (Brezzi et al. 2011) and other experience.

The new national classification was made according to successive groupings and matrix crossings based on the total population living in high-density areas, the share of the population in high-density areas, and location. Furthermore, to expand the understanding of urban and rural contexts, the methodology also uses accessibility to goods and services as a criterion for rural and urban space integration.

The share of the population living in high-density areas was calculated using the $1 \mathrm{~km}^{2}$ population grid with figures of the 2010 Population Census. High-density areas are defined as areas with 300 inhabitants $/ \mathrm{km}^{2}$ and where the sum of the population of eight neighbouring cells reaches a minimum of 3,000 inhabitants.

Table 1 resumes the degree of urbanisation concerning the classes of municipalities.

After the application of these rules, another criterion was considered: the proximity to urban centres. This new rule allows the classification of intermediate and predominantly rural municipalities as adjacent or remote. This subclassification was not used in the test conducted.

Data input for this classification is the 2010 Population Census, the Brazilian $1 \mathrm{~km}^{2}$ grid cells, and the commuting time using the transportation logistic map released by the IBGE in 2014 .

Regional Statistics, Vol. 9. No. 1. 2019: 72-84; DOI: 10.15196/RS090101 
Table 1

IBGE degree of urbanisation by classes of municipalities

\begin{tabular}{|c|c|c|c|c|}
\hline \multirow{2}{*}{$\begin{array}{l}\text { Population in high- } \\
\text { density areas, } \\
\text { inhabitants }\end{array}$} & \multicolumn{4}{|c|}{ Share of population in high-density areas } \\
\hline & More than $75 \%$ & $\begin{array}{l}\text { More than } \\
50 \text { to } 75 \%\end{array}$ & 25 to $50 \%$ & Less than $25 \%$ \\
\hline More than 50,000 & $\begin{array}{l}\text { Predominantly } \\
\text { urban }\end{array}$ & $\begin{array}{l}\text { Predominantly } \\
\text { urban }\end{array}$ & $\begin{array}{l}\text { Predominantly } \\
\text { urban }\end{array}$ & $\begin{array}{l}\text { Predominantly } \\
\text { urban }\end{array}$ \\
\hline $\begin{array}{l}\text { More than } 25,000 \\
\text { to } 50,000\end{array}$ & $\begin{array}{l}\text { Predominantly } \\
\text { urban }\end{array}$ & $\begin{array}{l}\text { Predominantly } \\
\text { urban }\end{array}$ & Intermediate & $\begin{array}{l}\text { Predominantly } \\
\text { rural }\end{array}$ \\
\hline $\begin{array}{l}\text { More than } 10,000 \\
\text { to } 25,000\end{array}$ & $\begin{array}{l}\text { Predominantly } \\
\text { urban }\end{array}$ & Intermediate & $\begin{array}{l}\text { Predominantly } \\
\text { rural }\end{array}$ & $\begin{array}{l}\text { Predominantly } \\
\text { rural }\end{array}$ \\
\hline $\begin{array}{l}\text { More than } 3,000 \\
\text { to } 10,000\end{array}$ & Intermediate & $\begin{array}{l}\text { Predominantly } \\
\text { rural }\end{array}$ & $\begin{array}{l}\text { Predominantly } \\
\text { rural }\end{array}$ & $\begin{array}{l}\text { Predominantly } \\
\text { rural }\end{array}$ \\
\hline Less than 3,000 & $\begin{array}{l}\text { Predominantly } \\
\text { rural }\end{array}$ & $\begin{array}{l}\text { Predominantly } \\
\text { rural }\end{array}$ & $\begin{array}{l}\text { Predominantly } \\
\text { rural }\end{array}$ & $\begin{array}{l}\text { Predominantly } \\
\text { rural }\end{array}$ \\
\hline
\end{tabular}

\section{Results}

Table 2 resumes the results for the degree of urbanisation of Brazilian municipalities using the three methodologies according to the rules presented previously.

Using the OECD Regional Typology (Methodology A), we can observe in Table 2 that most of the Brazilian municipalities are classified as intermediate $(49.9 \%)$ and the percentage of municipalities classified as intermediate is in the range from 40 to 60 in all the regions. Urban municipalities are the minority in Brazil (21.0\%), as well as in the Northern, Northeast, and Southern regions. Only 29.1\% of Brazilian municipalities are classified as rural, but these figures are expressive in the Northern, Northeast, and Southern regions, varying from 35.2 to $42.3 \%$. The Southeast and Central-West regions present the lowest number of rural municipalities, $214(12.8 \%)$ and $61(13.1 \%)$, respectively.

Comparing these results with the reality, we can conclude that the urban class is over-estimated while the rural class is under-estimated. This disagreement is caused in most cases by the misrepresenting of the local legislation that tries to promote personal or commercial interests through the raising of municipal taxes which, in turn, increase the municipality budget. (In general, areas defined as urban pay higher taxes than those defined as rural.)

If the DG REGIO/OECD methodology (Methodology B) is applied, most of the municipalities are rural $(56.2 \%)$, and the percentage of municipalities classified as rural is lower than $50 \%$ only in the Southeast region $(47.4 \%$ ), as we can see in Table 2. There are only $390(7.0 \%)$ urban or densely populated municipalities in Brazil. All the regions of the country present low percentages of urban

Regional Statistics, Vol. 9. No. 1. 2019: 72-84; DOI: 10.15196/RS090101 
municipalities and only the Southeast region has a figure higher than $10 \%$. An important number of municipalities are classified as intermediate: 2,047 (36.8\%) and all the Brazilian regions present figures similar to this value.

Table 2

\section{Degree of urbanisation of Brazilian municipalities,} by three methodologies, 2010

\begin{tabular}{|c|c|c|c|c|c|c|}
\hline \multirow{4}{*}{ Region } & \multicolumn{6}{|c|}{ Degree of urbanisation } \\
\hline & \multicolumn{2}{|c|}{ Rural } & \multicolumn{2}{|c|}{ Intermediate } & \multicolumn{2}{|c|}{ Urban } \\
\hline & Number & Percentage & Number & Percentage & Number & Percentage \\
\hline & \multicolumn{6}{|c|}{ of municipalities } \\
\hline \multicolumn{7}{|c|}{ Methodology A } \\
\hline North & 167 & 37.2 & 244 & 54.3 & 38 & 8.5 \\
\hline Northeast & 759 & 42.3 & 899 & 50.1 & 136 & 7.6 \\
\hline Southeast & 214 & 12.8 & 827 & 49.6 & 627 & 37.6 \\
\hline South & 418 & 35.2 & 521 & 43.9 & 249 & 21.0 \\
\hline Central-West & 61 & 13.1 & 285 & 61.2 & 120 & 25.8 \\
\hline Brazil & 1,619 & 29.1 & 2,776 & 49.9 & 1,170 & 21.0 \\
\hline \multicolumn{7}{|c|}{ Methodology B } \\
\hline North & 269 & 59.9 & 151 & 33.6 & 29 & 6.5 \\
\hline Northeast & 1,106 & 61.6 & 610 & 34.0 & 78 & 4.3 \\
\hline Southeast & 791 & 47.4 & 694 & 41.6 & 183 & 11.0 \\
\hline South & 725 & 61.0 & 389 & 32.7 & 74 & 6.2 \\
\hline Central-West & 237 & 50.9 & 203 & 43.6 & 26 & 5.6 \\
\hline Brazil & 3,128 & 56.2 & 2,047 & 36.8 & 390 & 7.0 \\
\hline \multicolumn{7}{|c|}{ Methodology C } \\
\hline North & 292 & 65.0 & 72 & 16.0 & 85 & 18.9 \\
\hline Northeast & 1,236 & 68.9 & 251 & 14.0 & 307 & 17.1 \\
\hline Southeast & 793 & 47.5 & 250 & 15.0 & 625 & 37.5 \\
\hline South & 767 & 64.6 & 109 & 9.2 & 312 & 26.3 \\
\hline Central-West & 275 & 59.0 & 64 & 13.7 & 127 & 27.3 \\
\hline Brazil & 3,363 & 60.4 & 746 & 13.4 & 1,456 & 26.2 \\
\hline
\end{tabular}

Note: Methodology A - OECD Regional Typology; Methodology B - DG REGIO/OECD methodology; Methodology C - IBGE national classification for municipalities. Here and in Table 4, deviations from 100.0\% result from rounding.

The results for both densely and sparsely populated classes appear to align with reality. However, the intermediate class is very wide and encompass different urbanisation 'nuances'. For instance, Mathias Lobato, a municipality with little more than 3,000 inhabitants in the state of Minas Gerais, is classified as 
intermediate as well as Palmas, the capital of the state of Tocantins, which is home to 230,000 people.

The IBGE national classification for municipalities (Methodology C) demonstrates that most of the municipalities in Brazil are rural (60.4\%) (see Table 2). This predominance can be observed in the whole country, with percentages higher than 50\% except for the Southeast region where that is $47.4 \%$. Intermediate municipalities are the minority in the country as well as in all the Brazilian regions. The values are approximately $9.2 \%$ for the Southern region and $16 \%$ for the Northern region. The percentage of municipalities classified as urban varies from 17.1 in the Northeast region to 37.5 in the Southeast region; the value for Brazil is 26.2 .

The results suggest that the urban class is over-estimated. We can observe municipalities with little more than 11,000 inhabitants classified as rural in Methodologies A and B - such as Canápolis in the state of Minas Gerais - being considered predominantly urban in Methodology $\mathrm{C}$ alongside the largest city of the country, São Paulo, with more than 11 million inhabitants.

According to Table 3 that compares the matching between the three methodologies evaluated, $\mathrm{A}$ and $\mathrm{B}$ match $\mathrm{C}$ in approximately $70 \%$ cases and A matches B to a lower degree (approximately 60\%).

For 2,328 municipalities (41.83\%) the degree of urbanisation using the three methods are the same, while 3,237 municipalities (58.17\%) present differences in the results.

Table 3

Matching of the three methodologies

\begin{tabular}{c|c|c|c|c}
\hline \multirow{2}{*}{} & \multicolumn{2}{|c|}{ B } & \multicolumn{2}{c}{ C } \\
\cline { 2 - 5 } & Match & No match & Match & No match \\
\hline A & 58.4 & 41.6 & 69.1 & 30.9 \\
B & - & - & 68.6 & 31.4
\end{tabular}

Note: Methodology A - OECD Regional Typology; Methodology B - DG REGIO/OECD methodology; Methodology C - IBGE national classification for municipalities.

We can suggest that the differences between $\mathrm{A}$ and $\mathrm{B}$, as well as $\mathrm{A}$ and $\mathrm{C}$, are due to imprecisions in rural-urban site definitions as the rules used in methodology $\mathrm{A}$ are based on different criteria, which are not precisely equal for all municipalities.

Surprisingly the greatest matching is between A and C: $69.1 \%$ or 3,843 municipalities and we believe that further investigation is necessary to explain this number.

The matching between $\mathrm{B}$ and $\mathrm{C}$ is also great (68.6\%) and this means that 3,816 municipalities have the same degree of urbanisation using both

Regional Statistics, Vol. 9. No. 1. 2019: 72-84; DOI: 10.15196/RS090101 
methodologies. Looking deeply into the differences between B and C, we computed the changes in each level of the degree of urbanisation (see Table 4).

The differences between the rural and intermediate degrees calculated by methodologies $\mathrm{B}$ and $\mathrm{C}$ can be due to a tough limit line between classes. A density slightly higher or slightly lower than 300 inhabitants $/ \mathrm{km}^{2}$ can probably change the degree of urbanisation from rural to intermediate (1-2) or from intermediate to rural (2-1).

The values for the change of the degree of urbanisation from intermediate to urban for the Southeast and Central-West regions (22.0\% and 20.0\%, respectively) are striking, although all the regions present high values in this respect. We suggest that these differences are due to the rules used to define the clusters in $\mathrm{C}$, but it should be further investigated.

Table 4

Changes in the degree of urbanisation using methodologies B and C

\begin{tabular}{|c|c|c|c|c|c|c|c|c|c|c|}
\hline \multirow{3}{*}{ Region } & \multicolumn{2}{|c|}{$1-2$} & \multicolumn{2}{|c|}{$1-3$} & \multicolumn{2}{|c|}{$2-1$} & \multicolumn{2}{|c|}{$2-3$} & \multicolumn{2}{|c|}{$0-0$} \\
\hline & $\begin{array}{c}\text { Num- } \\
\text { ber }\end{array}$ & $\begin{array}{c}\text { Percen- } \\
\text { tage }\end{array}$ & $\begin{array}{l}\text { Num- } \\
\text { ber }\end{array}$ & $\begin{array}{c}\text { Percen- } \\
\text { tage }\end{array}$ & $\begin{array}{c}\text { Num- } \\
\text { ber }\end{array}$ & $\begin{array}{c}\text { Perce- } \\
\text { tage }\end{array}$ & $\begin{array}{c}\text { Num- } \\
\text { ber }\end{array}$ & $\begin{array}{c}\text { Percen- } \\
\text { tage }\end{array}$ & $\begin{array}{c}\text { Num- } \\
\text { ber }\end{array}$ & $\begin{array}{c}\text { Percen- } \\
\text { tage }\end{array}$ \\
\hline & \multicolumn{10}{|c|}{ of changes } \\
\hline North & 14 & 3.1 & 2 & 0.4 & 39 & 8.7 & 54 & 12.0 & 340 & 75.7 \\
\hline Northeast & 41 & 2.3 & 18 & 1.0 & 189 & 10.5 & 211 & 11.8 & 1,335 & 74.4 \\
\hline Southeast & 64 & 3.8 & 75 & 4.5 & 141 & 8.5 & 367 & 22.0 & 1,021 & 61.2 \\
\hline South & 22 & 1.9 & 45 & 3.8 & 109 & 9.2 & 193 & 16.2 & 819 & 68.9 \\
\hline Central- & & & & & & & & & & \\
\hline West & 9 & 1.9 & 8 & 1.7 & 55 & 11.8 & 93 & 20.0 & 301 & 64.6 \\
\hline Brazil & 150 & 2.7 & 148 & 2.7 & 533 & 9.6 & 918 & 16.5 & 3,816 & 68.6 \\
\hline
\end{tabular}

Note: Methodology B - DG REGIO/OECD methodology; Methodology C - IBGE national classification for municipalities. Changes: 1-2 - from rural to intermediate; 1-3 - from rural to urban; 2-1 - from intermediate to rural; $2-3$ - from intermediate to urban; $0-0$ - the same degree of urbanisation.

\section{Conclusion}

As a general conclusion, we can point out that approaches using grid population data and rules based on population density and contiguity - like the methodology developed by the DG REGIO/OECD - offer a useful basis for regional statistics, once that comparisons between different countries or regions are crucial. The data generated using this methodology could be useful, for instance, for generating indicators for the UN's Sustainable Development Goals and for functional geographies, like large urban clusters that transpose administrative borders, as well

Regional Statistics, Vol. 9. No. 1. 2019: 72-84; DOI: 10.15196/RS090101 
as for studying the causes and effects of many socioeconomic phenomena, such as commuting and labour, and environmental phenomena, such as flooding and air quality.

Although the DG REGIO/OECD and the IBGE methodologies have many similarities, there were differences in the results. It is suggested that the main reason for these differences is conceptual, as the rules used in each methodology tries to materialize different concepts of urban and rural. Additionally, it is necessary to consider the purpose of the development and scale of each method. The Brazilian methodology intends to provide local detailed results that are adjusted to the national reality. On the other side, the purpose of the DG REGIO/OECD methodology is global and generic, as they intend to be applied globally and therefore needs to be suitable to many different configurations of human settlements.

Despite these differences, the methodology is useful and can help in understanding and solving different challenges (economic, demographic, social or environmental). The strength of the methodology is the possibility of applying it to any region of the world - as there is freely available population data for the whole world - and to a specific location, using more accurate population data released by official data producers.

We intend to continue the evaluation of the methodology proposed by the DG REGIO/OECD as it moves beyond the determination of the degree of urbanisation: it also deals with the definition of cities and functional urban areas.

\section{REFERENCES}

Brandmueller, T.-SCHÄFer, G.-Petri, E.-MÜller, O. (2017): Territorial indicators for policy purposes: NUTS regions and beyond Regional Statistics 7(1): 78-89. https://doi.org/10.15196/RS07105

BrezZI, M.-DijKSTRA, L.-RuIZ, V. (2011): OECD Extended Regional Typology: The Economic Performance of Remote Rural Regions OECD Regional Development Working Papers 2011/06, OECD Publishing. http://dx.doi.org/10.1787/5kg6z83tw7f4-en

Dijkstra, L.-Poelman, H. (2014): A harmonized definition of cities and rural areas: the new degree of urbanisation European Commission Regional Working Paper 01/2014. http://ec.europa.eu/regional_policy/sources/docgener/work/2014_01_new_ur ban.pdf

IBGE (2016): Grade Estatística IBGE, Rio de Janeiro. $\mathrm{ftp}$ //geoftp.ibge.gov.br/recortes_para_fins_estatisticos/grade_estatistica/censo _2010/grade_estatistica.pdf

IBGE (2017): Classificação e caracterização dos espaços rurais e urbanos do Brasil: Uma primeira aproximação IBGE, Rio de Janeiro.

https://biblioteca.ibge.gov.br/visualizacao/livros/liv100643.pdf

Regional Statistics, Vol. 9. No. 1. 2019: 72-84; DOI: 10.15196/RS090101 
OECD (Organisation for Economic Co-operation and Development) (2011): Regional Typology Directorate for Public Governance and Territorial Development. Available on http://www.oecd.org/governance/regional-policy/42392595.pdf

RAIN, D. R.-LONG, J. F.-RATClifFE, M. R. (2007): Measuring population pressure on the landscape: comparative GIS studies in China, India, and the United States Population and Environment 28: 321-336 https://doi.org/10.1007/s11111-0070055-4

UN (United Nations) (2014): Principles and Recommendations for a Vital Statistics System, Rev. 3. n https://unstats.un.org/unsd/demographic/standmeth/principles/M19Rev3en.pdf

\section{Appendix}

Figure 1

\section{Degree of urbanisation using OECD Regional Typology} (Methodology A)

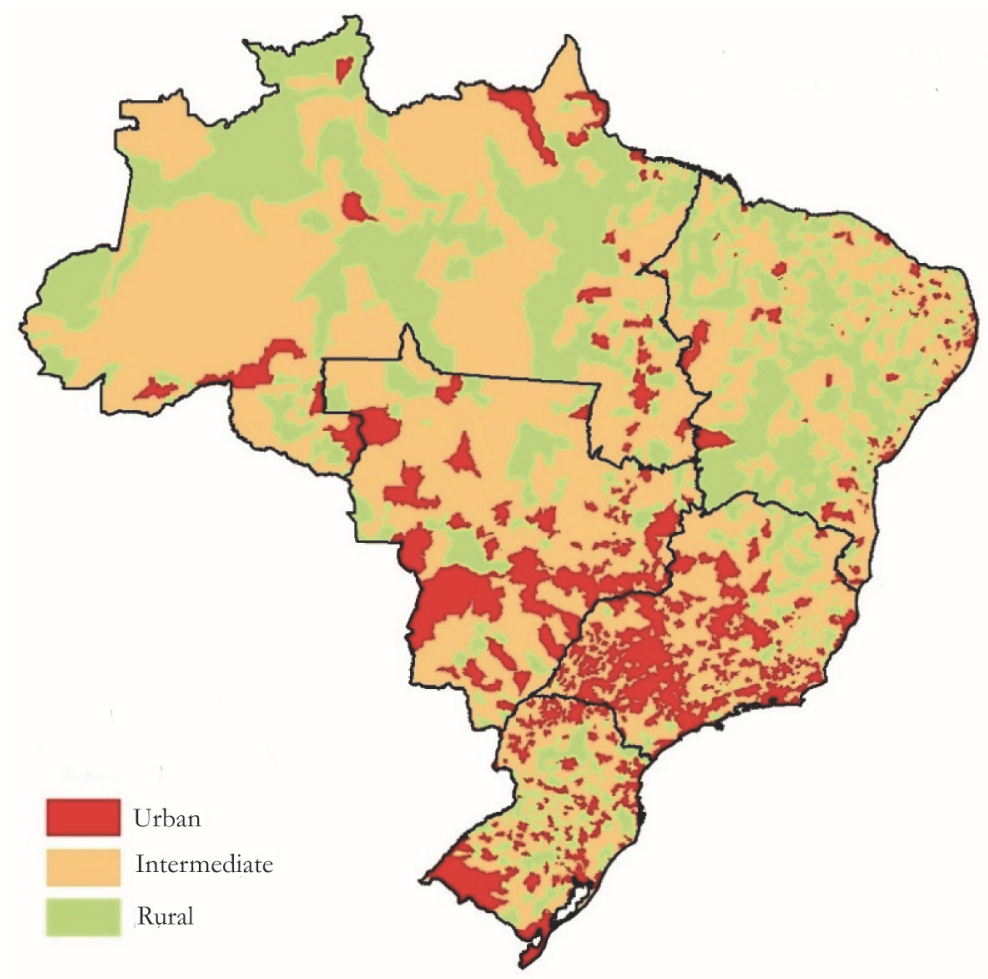

Regional Statistics, Vol. 9. No. 1. 2019: 72-84; DOI: 10.15196/RS090101 
Figure 2

Degree of urbanisation using DG REGIO/OECD methodology (Methodology B)

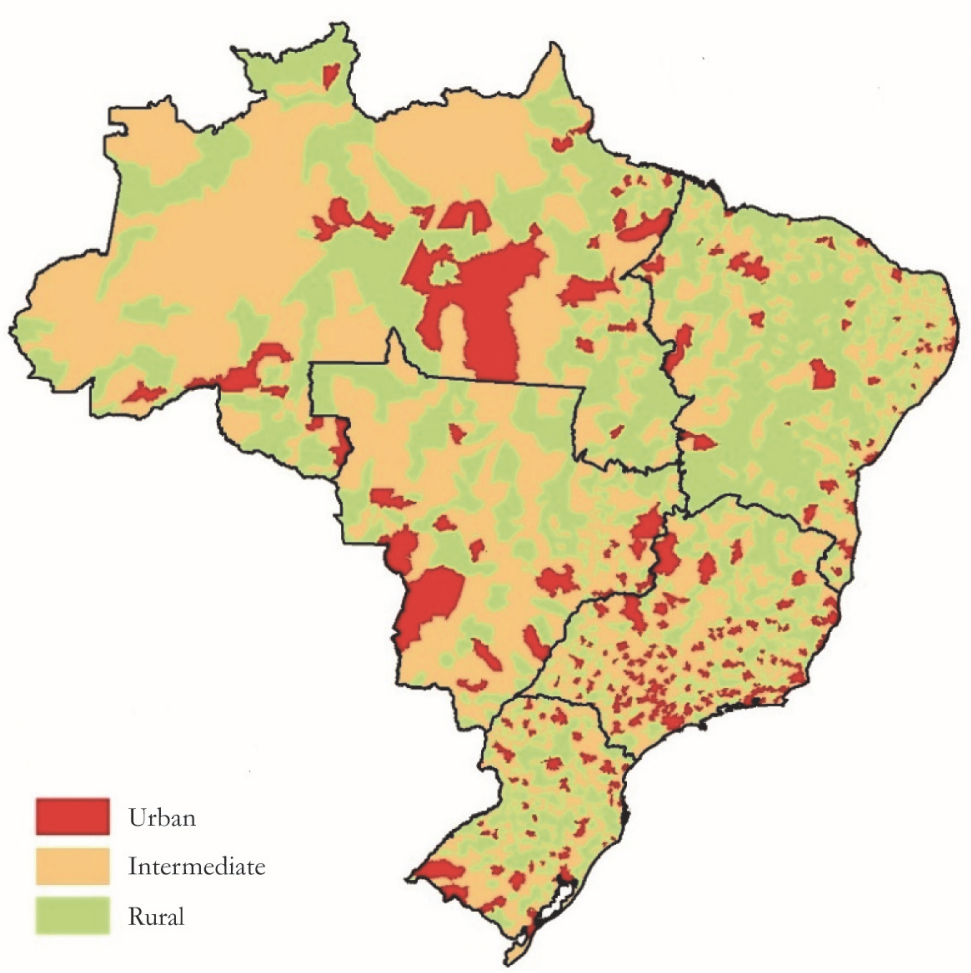

Regional Statistics, Vol. 9. No. 1. 2019: 72-84; DOI: 10.15196/RS090101 
Figure 3

Degree of urbanisation using the IBGE national classification for municipalities (Methodology C)

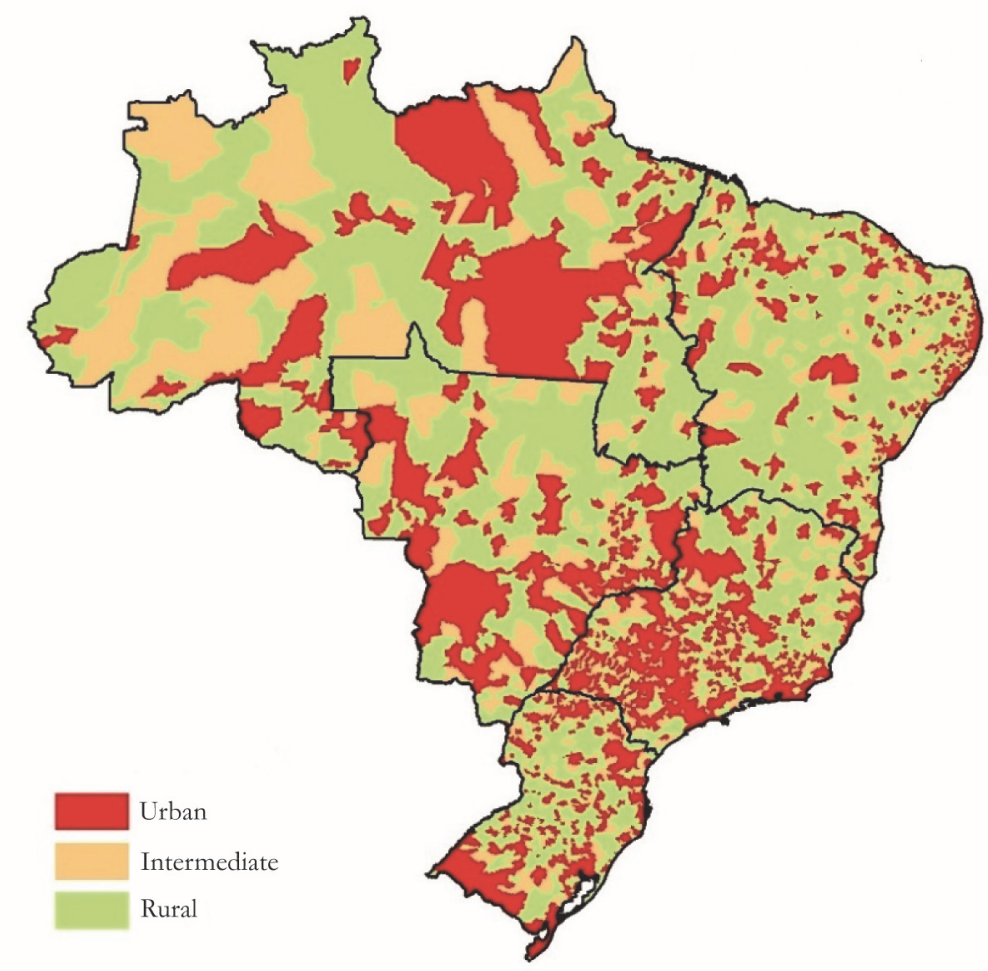

Regional Statistics, Vol. 9. No. 1. 2019: 72-84; DOI: 10.15196/RS090101 